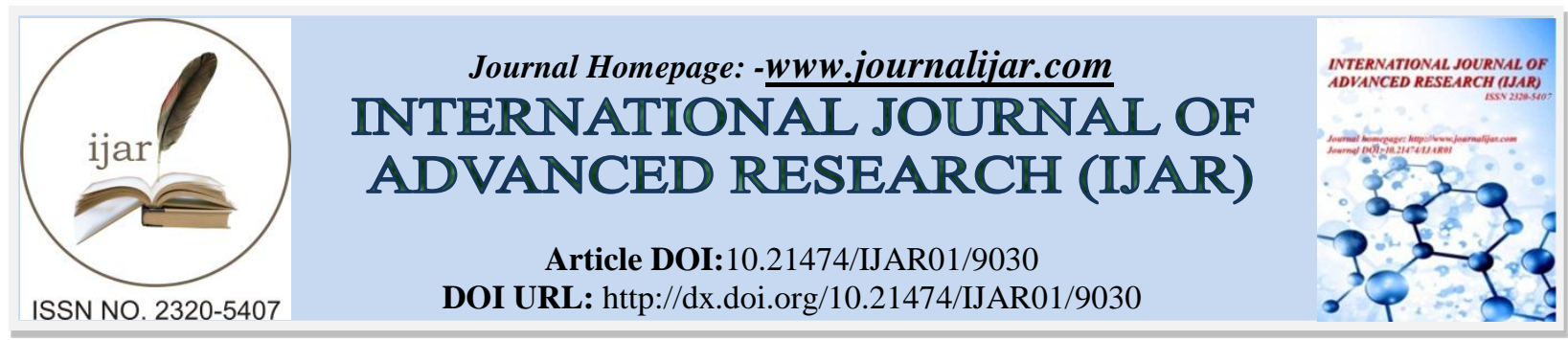

RESEARCH ARTICLE

\title{
THE EFFECT OF LEADERSHIP STYLE, INDIVIDUAL CAPABILITY, AND MOTIVATION ON AUDITOR PERFORMANCE WITH REWARD AS THE MODERATING VARIABLE.
}

Siti Nur Reskiyawati Said ${ }^{1}$, Andi Kusumawati ${ }^{2}$ And Sabir ${ }^{2}$.

1. Magister of Accounting, Faculty of Economics and Business, Hasanuddin University, Indonesia.

2. Department of Accounting, Faculty of Economics and Business, Hasanuddin University, Indonesia.

\section{Manuscript Info}

Manuscript History

Received: 08 March 2019

Final Accepted: 10 April 2019

Published: May 2019

Key words:-

Leadership Style, Individual Capability,

Motivation, Reward, Auditor

Performance.

\section{Abstract}

This study aims to provide a review of the effect of Leadership Style, Individual Capability, and Motivation on Auditor Performance and reward as a moderating variable. The object of the research is the auditor of the Regional Inspectorate of the Provincial Government of South Sulawesi. The population is 55 auditors. The sample technique used is the census method, which is a study that uses all members of the population to be sampled, so the number of samples is 55 respondents. Retrieving data using a questionnaire by analyzing data using moderated regression analysis (MRA) using SPSS version 22.

The results of the study show that: First, the leadership style has a positive and significant influence on the auditor's performance. Second, individual capabilities have a positive and significant effect on auditor performance. Third, motivation has a positive and significant effect on auditor performance. Fourth, rewards moderate the relationship of leadership style, individual capability, and motivation to auditor performance.

Copy Right, IJAR, 2019,. All rights reserved.

\section{Introduction:-}

Auditors are public accountants who provide services to auditors to check financial statements to be free of misstatements (Mulyadi, 2013). The auditor must be responsible for the results of the audit by meeting the audit standards oriented towards the public interest, this is because of the expectation of the community to create sound, credible, and reliable accounting practices. Arens et al. (2008) states that auditors who maintain their objectivity will act fairly without being subjected to pressure and requests from certain parties or personal interests.

The low performance of auditors in an organization can cause organizational barriers to achieving goals. There are many factors that can influence auditor performance including organizational factors such as leadership, rewards, and resources, individual factors such as ability and background, and psychological factors such as motivation, perception and attitude (Mangkunegara, 2009)

Thoha (2010) suggests that leadership style is a norm of behavior used by someone when the person tries to influence the behavior of others or subordinates. While according to Hasibuan (2016) means that leadership style is the way a leader can influence the behavior of subordinates so that it can encourage work passion, job satisfaction, and increase productivity.

Corresponding Author:-Siti Nur Reskiyawati Said.

Address:-Magister of Accounting, Faculty of Economics and Business, Hasanuddin University, Indonesia. 
According to Hariandja (2009) motivation is the factors that direct and encourage a person's behavior or desire to carry out an activity expressed in the form of a hard and weak business. While Robbins and Judge (2008) states that motivation is a process that explains the intensity, direction and perseverance of a person to achieve his goal.

Research on the effect of motivation on auditor performance has been carried out several times in Indonesia. Among them, research from Azhar (2013), Panjaitan and Jatmiko (2014), Marita and Gultom (2018), and Permana (2016). All three examined the effect of motivation on auditor performance. The difference in research on the object under study, Azhar examined Pekanbaru public accounting firm (2013), Panjaitan and Jatmiko (2014) examined public accounting firms in DKI Jakarta, Marita and Gultom (2018) researching at PT Perkebunan Nusantara IV Medan, while Permana ( 2016) researching the Financial and Development Supervisory Agency.

Research results from Permana (2016), Marita and Gultom (2018), and Panjaitan and Jatmiko (2014) show that motivation has a significant effect on auditor performance or quality. This result is contrary to Azhar's (2013) study which found that motivation does not affect auditor performance. This is due to the presence or absence or the magnitude of the influence of motivation given such as support, morale, bonuses at work may not necessarily affect auditor performance.

Research that examines the relationship of individual capabilities with auditor performance has also been carried out and shows inconsistency because it has different results. Ongkorahardjo (2008) states that individual capabilities have a significant effect on auditor performance, this is in line with the research of Supriatna (2014) which states that individual capabilities have a positive relationship to auditor performance so that performance improvements related to audit tasks are absolutely necessary. While Sudibyo (2014) found that individual capabilities did not significantly influence auditor performance.

Trisnaningsih (2007), Rofingatun (2018), Arumsari and Budiartha (2014), Kurniawan et al (2017), Juliningtyas (2012) found that leadership style had a significant effect on auditor performance. This is because the leader in the KAP concerned is a leader who applies good and acceptable ways to lead the auditor, so they can be encouraged to work well. This is contrary to the research of Widhi and Setyawati (2015) who found that leadership styles did not influence auditor performance.

Auditors' performance according to Mulyadi (2008) is a public accountant who conducts an objective examination of the financial statements of a company or organization that aims to determine whether the financial statements have been fairly presented in accordance with the generally accepted accounting principles in all material matters, positions financial and business results of the company and in carrying out the auditor must comply with the Indonesian Public Accountants code of ethics and Auditing Standards.

The Goal Setting Theory proposed by Locke (1978) explains the relationship between goals set with work performance (performance). the basic concept of this theory is that someone who understands the purpose (what is expected by the organization to him) will affect his work behavior. This theory states that individual behavior is governed by ideas (thoughts) and one's intentions. Goals can be seen as goals or levels of performance that individuals want to achieve. Goal setting theory implies that an individual is committed to the goal (Robbins, 2008). Ifan individual is committed to achieving his goals, then this will affect his actions and affect the concentration of his performance.

The motivation theory of Abraham Maslow explains that in all human beings there are five levels of need (Robbins, 2003), namely: Psychological Needs, Safety Needs, Social Needs, Reward Needs, and Self-Actual Needs. This theory explains that basically there is no need that can be fully fulfilled, but certain needs that have been satisfied substantially are no longer motivational drivers. In this theory separated by the highest and lowest levels. Psychological needs and the need for security are described as the lowest level of need, while social needs, respect and self-actualization are placed in the highest level

This study is a replication cited from a journal entitled "the effect of human capital on auditor performance in KAP in Bandung" which was examined by Supriatna (2007). The reason for replicating this journal is to be used as research material, namely to re-analyze several variables, namely leadership style, individual capability, and motivation and adding reward as a moderating variable. 
The difference with previous research is that this research is adding variables to study variable rewards as moderating the influence of leadership style, individual capability, motivation on auditor performance. Reward is chosen as a moderating variable because reward can increase one's efforts to provide good performance which will be shown through factors that influence performance. This is supported by expectancy theory stated by Victor Vroom that a person will be motivated to increase efforts if he believes the effort will lead to a good performance assessment, then good performance evaluation will encourage the organization to provide organizational rewards (reward) so that the reward can satisfy the person's personal goals.

Alshbiel and Zeaud (2011) found that rewards have a positive effect on auditor performance. This shows that the higher the reward given to the auditor, the better the performance shown. Reward according to language, comes from English which means award or gift. Whereas according to the term, an award (reward) is a form of appreciation to a certain achievement given either by individuals or an institution. (Bangun, 2012). So rewards (rewards) give something to others as rewards or mementos / souvenirs. Awards given to others can be anything, depending on the wishes of the giver. The form of reward can also be adjusted to the achievements (Djamarah, 2008).

Bangun (2012) explained that the Award can be in the form of financial and non-financial aspects, but still gives pride to anyone who receives it. The higher the status and position of someone in the company, the higher the need for self-esteem concerned. Whereas according to (Dessler, 2009) more emphasize this reward as a form of positive benefit so that it is not always reward in material forms such as salaries, bonuses and benefits, but it can also be in the form of praise, awards or other positive things.

Based on the description above, this research is entitled The Effect of Leadership Style, individual capability, and Motivation on Auditor Performance by being moderated by Variable Reward. Variable rewards will bring passion and good work spirit in the hope that it will improve auditor performance.

\section{Theoretical Review}

\section{a. Goal Setting Theory}

The theory proposed by Locke (1978) explains the relationship between goals set with work performance. The basic consept of this theory is that someone who understand the purpose (what is expected by the organization to him) will affect his work behavior. This theory states that individual behavior is governed by ideas and one's intentions. Goals can be seen as goals or levels or performance that individual want to achieve. If an individual is committed to achieving his goals, this will affect his actions and affect the consequences of his performance.

According to this theory one of the characteristics of behavior that has a commonly observed goal is that the behavior continues until the behavior reaches its completion, once a person starts something (such as a job, a new project), he continues to urge until the goal is reached. This theory also states that individual behavior is governed by ideas (thoughts) and one's intentions. Goals can be seen as goals or levels of work that individuals want to achieve. Goal setting theory implies that an individual is committed to the goal (Robbins, 2008). Ifan individual is committed to achieving his goals, then this will affect his actions and affect the concentration of his performance

\section{b. Motivation Theory}

The motivational theory of Abraham Maslow is one of the most famous motivational theories. The hypothesis says that in all humans there are five levels of need (Robbins, 2003), namely:

1. Psychological Needs are the most basic hierarchy of htunan needs, namely hunger, thirst, protection and other physical needs.

2. The need for security is a necessity that includes security of protection from the dangers of workplace accidents, guarantee of the continuity of his work and guarantee of his old age.

3. Social needs, namely the need for friendship, affiliation and closer interaction with others. In organizations related to the need for a compact working group, or good supervision

4. Reward needs

5. These needs include the desire to be respected, valued for one's achievements, recognition of one's abilities and expertise and the effectiveness of one's work.

6. Self-actualization needs

7. Self-actualization is the drive to become someone according to his ambition, which includes growth, 
achievement of potential and fulfillment of self-needs.

\section{Leadership Style}

Leadership style is a set of characteristics used by leaders to influence subordinates so that organizational goals are achieved or it can also be said that leadership styles are behavioral patterns and strategies that are liked and often applied by a leader. Leadership style that shows, directly or indirectly about a leader's belief in the abilities of his subordinates. This means that leadership style is behavior and strategy, as a result of a combination of philosophy, skills, traits, attitudes, which are often applied by a leader when he tries to influence the performance of his subordinates (Rivai et al, 2014). Furthermore according to Yukl (2010) leadership style is a process to give influence to other people with the aim that they can agree and understand what must be done so as to provide effective results to achieve common goals.Sulistyani (2008) explains that the basic elements of leadership which consist of the capacity, capability, and personality of the leader are things that play an important role in determining the effectiveness of an individual's leadership. Capacity is the background that is owned by the leader regarding the level of ability, both in terms of skill and knowledge obtained formally or non-formally which can provide benefits for his leadership. Capability (ability) is an attitude that is reflected from a leader by giving full rnsponsibility for all the consequem.;es that will be faced by the organization. While personality (personality) is the nature or character inherent in a person.

\section{Individual Capability}

Moeheriono (2009) defines individual capabilities as a basic characteristic of a person that indicates how to think, behave, and act and draw conclusions that can be done and maintained by someone at a certain period of time. While Robbins and Timothy (2008) define individual capability as an ability possessed by individuals in various activities. Individual capability shows the individual's ability to complete a job in accordance with the burden and responsibility given. Capability shows the emotional intelligence that an individual has to try to finish work on time.According to Mayo (2000) individual capabilities include five criteria, namely: 1) personal capabilities, namely the ability of a person from within himself, including the appearance, thoughts, actions, and feelings, 2) professional and technical know-how, namely the ability to behave professional in every situation and condition and the willingness to transfer knowledge from seniors to juniors, 3) Experience, namely someone who is competent and has long experience in the field and has an open attitude to experience, 4) The network and range of personal contacts, namely someone who is said to be competent if he has a wide network or connection with anyone, especially people related to his profession, 5) The values and attitudes that influence actions

\section{e. Motivation}

According to Samsuddin (2010) argues that motivation is a process that influences or encourages from the outside of a person or work group so that they want to implement something that has been determined, whereas according to Sondang (2009: 102) states that motivation is a driving force for someone to contribute as much as possible for the success of the organization to achieve its objectives. Furthermore Robbins and Judge (2008) states that motivation is a process that explains the intensity, direction and perseverance of a person to achieve his goal.According to Mangkunegara (2014) motivation, a person's productivity is largely determined by the 'mental virus' that is in him. Mental viruses are mental conditions that encourage a person to be able to achieve maximum achievement. The mental virus in question consists of three urges of need, namely:a. The need for achievement, is the need to achieve success, which is measured by the standard of opportunity in a person.b. Affiliated needs are a need for warmth and support in relation to othersc. The need for strength, is the need to master and influence the situation of others in order to become dominant or controlling.

\section{f. Reward}

Bangun (2012) an award (reward) is a form of appreciation to a particular achievement given either by individuals or an institution. Awards can be in the form of financial and non financial aspects, but still give pride to those who receive them. The higher the status and position of someone in the company, the higher the need for self-esteem concerned. Whereas according to (Dessler, 2009) more emphasize this reward as a form of positive benefit so that it is not always reward in material forms such as salaries, bonuses and benefits, but it can also be in the form of praise, awards or other positive things.Performance-based rewards encourage employees to change their tendency to fulfill their own interests so that they are passionate about meeting organizational goals (Mulyadi, 2008). Thus reward is all forms of financial and nonfinancial returns received because of services provided by the organization. 


\section{g. Auditor Performance}

Management success in an organization is very dependent on the performance of its human resources. Wibowo (2014) stated that performance is the result achieved by the work done. Performance is about what is done and how to do it. Whereas, Mangkunegara (2014) explains that performance comes from the word job performance (work performance) or actual performance (actual achievement achieved by someone). So performance is the result of work achieved both in terms of quality and quantity for the implementation of duties and responsibilities carried out by an employee.Moeheriono (2012) describes performance or performance as a description of the level of achievement of an activity program or policy in realizing the goals, vision, and mission of the organization as outlined in the strategic planning of an organization. Furthermore, Wirawan (2009) mentions that performance stands for work energy kinetics whose equivalent in English is performance. Performance is the output produced by functions or indicators of a job ot a profession in a given time. While Akbar (2015) states that auditor performance is the result of the achievement of an auditor in carrying out the tasks assigned to him based on the skills, experience, and sincerity of time measured by considering quantity, quality, and timeliness.

\section{h. Hypothesis}

$\mathrm{Hl}$ : The leadership style has a positive effect on auditor performance.

$\mathrm{H} 2$ : Individual capability has a positive effect on auditor performance.

H3: Motivation has a positive effect on auditor performance.

H4: Reward moderates the influence of leadership style relationships, individual capabilities and motivation, on auditor performance.

\section{Research Methods:-}

This research uses explanatory research (quantitative research) with a quantitative approach that aims to determine the causality relationship between variables through a hypothesis testing (hypothesis testing). The method used in this study is the census method obtained from the distribution of questionnaires to the auditor which contains variables related to the research subject. This research will be conducted at the Inspectorate of South Sulawesi Province, having its address at Jln. Andi Pangerang Pettarani No. 100. This study will be conducted in approximately 1 month. This time is used to obtain data and analyze research data.The total population in this study were 55 people with details of the middle auditor auditor 27 people, young auditors 22 people, middle staff auditors 6 people. While the sampling technique used is the census method. The reason for choosing the location at the Inspectorate of South Sulawesi Province was because the audits carried out by auditors were still in the spotlight of the community, therefore an increase in auditor performance was still very much needed.The data used in this study are primary data and secondary data. The method of data collection in this study was to fill out questionnaires and conduct direct interviews in a structured manner to several respondents. The questionnaire was filled with an ordinal scale by measuring attitudes towards the questions raised by a score of 1 (STS: strongly disagree), score 2 (TS: disagree), score 3 (N: neutral), score 4 (S: agree), and score 5 (SS: strongly agree).

\section{Research Variables And Operational Definitions}

1. Independent variable (independent variable), this variable is a variable that affects or is the cause of change or the emergence of dependent variables (Sugiyono, 2014). The independent variables in this study are Leadership Style (X1), Individual Capability (X2), Motivation (X3).

2. Leadership Style (X1). The leadership style that is the focus of this research is the participatory leadership style which emphasizes the existence of a good relationship between superiors and subordinates which is demonstrated through two-way communication, teamwork and mutual respect. The leadership style used in this study is divided into two: consideran leadership style and leadership structure style. The leadership style variables in this study were measured using instruments developed by Gibson (2000).

3. Individual Capability (X2). Individual capability is the potential possessed by someone with an indication of having professional abilities, experience, connections, and a good attitude. Individual capability variables in this study were measured using instruments developed by Mayo (2000), with experience, professional abilities, education, training, timeliness and precision in work.

4. Motivation (X3). Motivation is the driving force for someone to contribute as much as possible for the success of the organization to achieve its goals. Motivational variables in this study were measured using instruments developed by Ganesan and Barton (1996). Each respondent was asked to answer 5 questions that measure sincerity in work, the desire to learn something different and new, a preference for chatlenging and difficult work, liking work under pressure and deadline. 
5. Moderating or moderating variables are variables that have a strong influence on dependence on the relationship between the dependent variable and the independent variable. The moderating variable in this study is reward (Z) which is the compensation given by an organization to someone on the basis of the performance assessment in question. Rewards are measured using a research instrument developed by Mitchell and Pravin (1976). This variable asks respondents to answer five questions that measure job satisfaction, self-esteem, creativity development, coworker appreciation, and recognition, and awards given by superiors.

6. Dependent variable (dependent variable). The dependent variable in this research is the auditor's performance (Y) which is the result of work in quality and quantity achieved by an employee in performing his duties in accordance with the responsibilities given. Auditor performance variables in this study were measured using instruments developed by Fuad Masud (2004) with indicators of Cooperative Ability, Job Quality, Technical Ability, Initiative, Passion, Durability I Reliability, Job Quantity

\section{Analysis Method:-}

The analytical method used in this study is multiple regression analysis. Before conducting multiple regression analysis, the data quality test is first, namely validity test and reliability test and also performs classic assumption tests, namely, normality test, heteroscedasticity test, linearity test, multicollinearity test, and autocorrelation test. Multiple linear regression analysis is used to detennifie the correlation between the dependent and independent variables and to predict the state (rise and fall) of the dependent variable, iftwo or more independent variables as predictor factors are manipulated (increase in value decreases).

In this study there are also interaction variables. To test the interaction effect of the moderating variable, where the influence of leadership style, individual capability, motivation on auditor performance is moderated by reward, using Moderated Regression Analysis (MRA), the application of multiple linear regression where the equation contains interaction elements (multiplying two or more variables independent).

\section{Analysis Results:-}

Based on the results of research data analysis, it can be seen that the influence of leadership style, individual capability, and motivation partially influences the auditor's performance. then the influence of leadership style, individual capabilities, and motivation after being moderated by reward shows a positive and significant influence. This means that moderating variables strengthen the influence of leadership style, individual capabilities, and motivation on auditor performance.

Table 5.18:-Results of Multiple Regression Before Interacting with Moderating Variables Coefficients

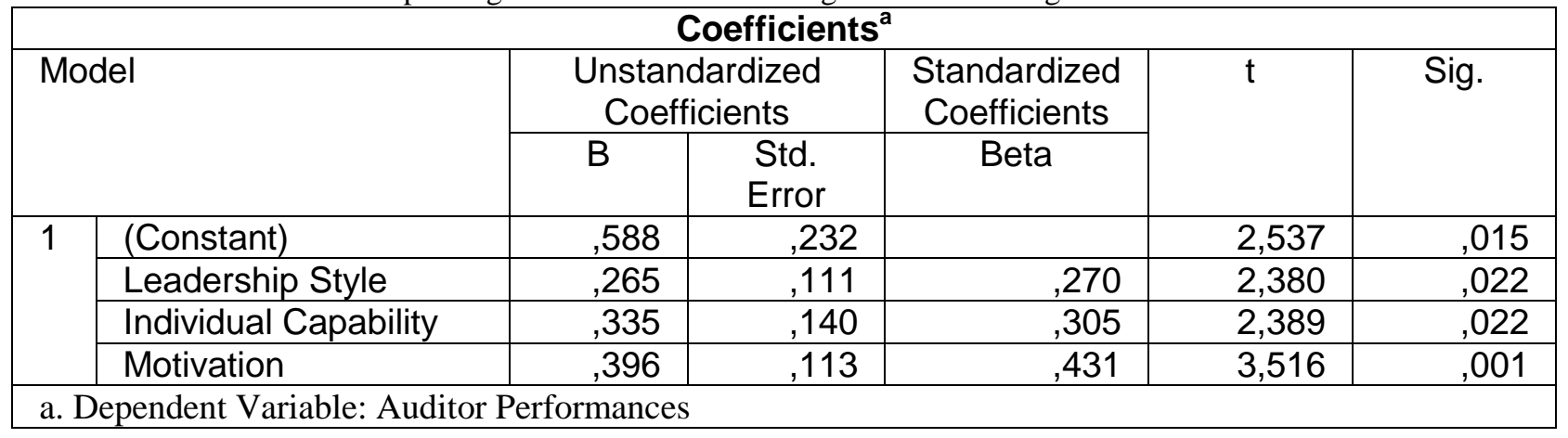

Based on table 5.18 above, then the form of regression equation before interacting with moderating variables is as follows.

$\mathrm{Y}=0.588+0.265 \mathrm{X} 1+0.335 \mathrm{X} 2+0.396 \mathrm{X} 3+\mathrm{e} \ldots(1)$

Equation (1) above shows that the Goeftfoient values of all independent variables, namely the leadership style variable, individual capability, motivation have a significant relationship to the dependent variable, the auditor performance variable. This can be seen from the significant probability values of leadership style variables of 0.022 , individual capabilities of 0.022 , motivation of 0.001 ( sig. <0,05).

Based on the results of the tests that have been conducted, the results of hypothesis testing can be summarized as follows. 


\section{Testing the First Hypothesis}

Based on the coefficients in table 5.18, the leadership style variable shows the value of $\mathrm{t}$ count of 2.380 while the value of $\mathrm{t}$ table with the degree of freedom (df) $45-5=45-5-1=39$ and $\mathrm{a}=5 \%$ (two directions) shows the value of $\mathrm{t}$ table $=2.014$. Thus $\mathrm{t}$ count $2.380>\mathrm{t}$ table 2.014 . The results of the significance test also show the probability value of the leadership style variable of 0.022 .

Based on these two results, hypothesis 1 states that leadership styles have a significant influence on auditor performance, accepted.

\section{Testing of the Second Hypothesis}

Based on the coefficients in table 5.18, the $t$ test of capability variable shows the value of $t$ count of 2.389 while the value of $\mathrm{t}$ table with the degree of freedom (df) $\mathrm{n}-\mathrm{k}=45-5-1=39$ and $\mathrm{a}=5 \%$ (two directions) then shows the value $\mathrm{t}$ table $=2.014$. So $\mathrm{t}$ count $2.389>\mathrm{t}$ table 2.014 . The results of the significance test also show the probability value of individual capability variables of 0.022 . Thus hypothesis 2 which states individual capabilities have a significant effect on auditor performance, is accepted.

\section{Testing of the Third Hypothesis}

Based on table 5.18 coefficients, the $t$ test of the motivation variable shows the value of $t$ count of 3.516 while the value of $\mathrm{t}$ table with the degree of freedom (dt) $\mathrm{fi}-\mathrm{k}=45-5-5=39$ and $\mathrm{a}=5 \%$ (two directions) then indicates the value of $\mathrm{t}$ table $=2.014$. So $\mathrm{t}$ count 3.516>t table 2.014. The results of the significance test also show the probability variable of the motivation variable of 0.001 . Thus hypothesis 3 which states that motivation has a significant effect on auditor performance, is accepted

Then the regression test for all independent variables is carried out by interacting with the moderating variable. The regression test results after interacting with the reward (z) variable can be seen in the following table

\begin{tabular}{|c|c|c|c|c|c|c|}
\hline \multicolumn{7}{|c|}{$\begin{array}{c}\text { Table 5.19 } \\
\text { Coefficients }^{\mathrm{a}}\end{array}$} \\
\hline \multirow{2}{*}{\multicolumn{2}{|c|}{ Model }} & \multicolumn{2}{|c|}{$\begin{array}{l}\text { Unstandardized } \\
\text { Coefficients }\end{array}$} & \multirow{2}{*}{$\begin{array}{c}\begin{array}{c}\text { Standardized } \\
\text { Coefficients }\end{array} \\
\text { Beta }\end{array}$} & \multirow[t]{2}{*}{$\mathrm{t}$} & \multirow[t]{2}{*}{ Sig. } \\
\hline & & $\mathrm{B}$ & Std. Error & & & \\
\hline \multirow[t]{5}{*}{1} & (Constant) & 2,088 & ,109 & & 19,127 &, 000 \\
\hline & Reward & $-2,451$ & ,419 & $-1,511$ & $-5,848$ &, 000 \\
\hline & Leadership Style*Reward & ,947 & ,431 & ,453 & 2,197 & ,034 \\
\hline & Individual Capability*Reward & 1,269 & ,555 & ,617 & 2,285 &, 028 \\
\hline & Motivation*Reward & 1,536 &, 448 & ,709 & 3,424 &, 001 \\
\hline
\end{tabular}

\section{Table 5.19 Results of Multiple Regression After Interacting with Moderation variables}

Based on the results of the regression test after interacting with the moderating variable, the form of the equation is arranged as follows.

$\mathrm{Y}=2,088-2,451 \mathrm{Z}+0,947 \mathrm{X} 1 . \mathrm{Z}+1,269 \mathrm{X} 2 . \mathrm{Z}+1,536 \mathrm{X} 3 . \mathrm{Z}+\mathrm{e} \ldots(2)$

Equation (2) above shows that the coefficient value of the leadership style variable, individual capability, motivation after interacting with the moderating variable has a significant relationship to the dependent variable, the auditor performance variable. This can be seen from the significant probability value of the capability variable of leadership style * reward of 0.034 , individual capability* reward of 0.028 , motivation * reward of 0.001 . Thus the reward variable moderate the leadership style, individual capability, and motivation on auditor performance.

\section{d. Testing of the Fourth Hypothesis}

Testing the moderation variable is done by comparing the determinant coefficient values before and after the interaction of the moderating variable. Based on the determinant coefficient value before interaction (Table 5.18 ) it is found that the $\mathrm{R}$ value is $0.721, \mathrm{R} 2$ is 0.520 . While the determinant coefficient value after interaction (Table 5.19) shows that the $\mathrm{R}$ value is 0.723 , $\mathrm{R}$ Square 0.523 Using the results of the comparison of the determinant coefficient values before and after the moderating variable interaction can be seen that there is 
an increase in the value R. Increase R2 before the interaction ( Table 5.18) which is 0.520 and R2 value (Table 5.19) after the interaction is 0.523 , it can be seen that there is an increase in the value of $R 2$. The increase in the value of R2 can be concluded that the reward variable functions as moderation I strengthens the relationship of leadership style, individual capability, motivation with auditor performance. Thus hypothesis 4, namely reward can moderate the relationship between leadership style, individual capability, motivation with auditor performance, is accepted.

\section{Discussion:-}

\section{The effect of leadership style (XI) on auditor performance (Y)}

Based on the results of the $t$ test on the leadership style variable shows the value of $t$ count of 2.380 while the value of $\mathrm{t}$ table shows the value of $\mathrm{t}$ table $=2.014$. So $\mathrm{t}$ count $2.380>2.014$ thus hypothesis 1 which mentions leadership style has a significant influence on auditor performance, accepted.

The findings of this study indicate that leadership styles can influence auditor performance. The meaning of participatory leadership style is indicated by the close relationship between superiors and subordinates, mutual trust, teamwork, and the establishment of good communication can improve the quality of cooperation between auditors and leaders (audit team leaders) so that it will have an impact on the performance provided.

The mean value of the leadership style variable is 4.52 , indicating that in general the leadership style with indicators is the relationship between superiors and subordinates, mutual trust, teamwork, mutual respect and communication, and relationships between colleagues the auditor inspectorate of the province of South Sulawesi was considered quite good.

The results of this study support the Goal Setting Theory proposed by Locke ( 1978) describes the relationship between goals set with work performance (performance). the basic concept of this theory is that someone who understands the purpose (what is expected by the organization to him) will affect his work behavior. Participatory leadership style is an external factor that is used by a leader when trying to influence the behavior of others or subordinates. This is done persuasively and creates harmonious cooperation between superiors and subordinates. Leaders motivate subordinates to feel they have an organization, while subordinates participate in providing suggestions, ideas, and considerations in making decisions.

This result is consistent with research conducted by Trisnaningsih (2007), Rofingatun (2018), Arumsari and Budiarta (2014) which states that leadership styles can influence auditor performance creativity in carrying out their duties as members of the organization because the leader is one of the determining factors for success or whether or not an organization.

\section{The effect of individual capabilities (X2) on auditor performance (Y)}

Based on the results of the $t$ test on individual capability variables show the value of t count equal to 2,389 while the value of $\mathrm{t}$ table shows the value of $\mathrm{t}$ table $=2,014$. So $\mathrm{t}$ count $2.389>2.014$ thus hypothesis 2 which states that individual i::apabilities have a significcant effect on auditor performance, accepted.

The mean value of the individual capability variable is 4.46 with a standard deviation of 0.31 . This shows that in general the individual capability of the auditor at the South Sulawesi Provincial Inspectorate is assessed by indicators such as experience, professional ability, education, training, and accuracy. time and accuracy in work are considered to be quite good.

The findings of this study indicate that individual capabilities influence auditor performance. This is indicated by the components of capability formation that are owned, nameJy experience, professional ability, education, training, as well as the timeliness and accuracy in work.

The results of this study support the Goal Setting Theory proposed by Locke (1978) describes the relationship between goals set with work performance (performance). the basic concept of this theory is that someone who understands the purpose (what is expected by the organization to him) will affect his work behavior. individual capabilities are internal factors because individual capabilities are capabilities possessed by individuals in carrying out various activities according to their duties and responsibilities. Behavior caused by internal factors is behavior 
that is believed to be under control or comes from within an individual such as personality traits (motivation, and ability)

This result is consistent with research conducted by Supriana (2014), Ongkorohardjo (2008) and Sujana (2012) which concluded that there is a relationship between individual capabilities and auditor performance. This indicates that individual capabilities have a positive relationship with auditor performance so that knowledge, abilities, skills and innovations that are part of individual capabilities are absolutely needed by auditors to improve their performance.

\section{The effect work motivation (X3) on auditor performance $(\mathrm{Y})$}

Based on the results of the t test on the motivation variable shows the value of $t$ count of 3.516 while the value of $t$ table shows the value of $\mathrm{t}$ table $=2.014$. So $t$ count $3.516>2.014$ thus hypothesis 3 which states that motivation has a significant effect on auditor performance, is accepted.

The mean value of the work motivation variable is 4.50 with a standard deviation of 0.37 , this indicates that in general the auditor's work motivation in the South Sulawesi Province inspectorate is an indicator of seriousness in work, liking challenging work, always wanting to progress, set work goals, and satisfaction with work is considered quite good.

The findings of this study indicate that work motivation affects auditor performance. This is indicated by indicators that are fulfilled by auditors, namely seriousness in improving performance, liking challenging jobs, having a sense of always wanting to progress, setting work goals and satisfaction with work. The results showed that on average, respondents agreed or indicated that the auditor's inspectorate's perception of motivation was relatively high.

The results of this study support the Goal Setting Theory proposed by Locke (1978) describes the relationship between goals set with work performance (performance). the basic concept of this theory is that someone who understands the purpose (what is expected by the organization to him) will affect his work behavior. Work motivation is an internal factor because motivation is the driving force for someone to make as much contribution as possible for the success of the organization. Behavior caused by internal factors is behavior that is believed to be under control or comes from within an individual such as personality traits (motivation, and ability)

This result is consistent with research conducted by Permana (2016), Marita and Gultom (2018) and Panjaitan and Jatmiko (2014) which show that motivation has a significant effect on auditor performance.

The effect of moderating rewards on leadership style, individual capability, motivation and auditor performance. $\mathrm{R} 2$ value before interaction is 0.520 and $\mathrm{R} 2$ value after interaction is 0.523 , it can be seen that there is an increase in $\mathrm{R} 2$ adjusted R2 Increase the Adjusted R2 value from 0.520 to 0.523 . It can be concluded that the reward variable functions as a moderation or strengthens the relationship of leadership style variables, individual capabilities, motivation and auditor performance. Thus hypothesis 4, namely reward can moderate the leadership style, individual capability, and motivation on auditor performance, accepted. The mean value of the reward variable is 3.97 with a standard deviation of 0.43 , this shows that in general the auditor's work motivation in the South Sulawesi Province inspectorate is indicators of satisfaction with reward (additional employee income), creativity, peer appreciation work, and recognition from superiors is considered quite good.

The findings of this study indicate that reward moderates or strengthens the relationship between leadership style, individual capability and motivation on auditor performance. this is indicated by an increase in the value of R2 before the interaction of 0.520 and the value of $\mathrm{R} 2$ after the interaction is 0.523 .

The results of this study support the Goal Setting Theory proposed by Locke (1978) describes the relationship between goals set with work performance (performance). the basic concept of this theory is that someone who understands the purpose (what is expected by the organization to him) will affect his work behavior.

The results of this study also support the motivational theory of Abraham Maslow formulating that humans in their workplaces are motivated by a desire to satisfy a number of needs that exist within a person. The need for rewards that are positioned as high-level needs is considered to he able to encourage one's performance. 


\section{Conclusion:-}

The conclusions are :

1. The leadership style influences the performance of the inspector of the South Sulawesi provincial auditor. The results of this study support the theory of Goal Setting Theory which explains the relationship between goals set with work performance (performance). the basic concept of this theory is that someone who understands the purpose (what is expected by the organization to him) will affect his work behavior. Inaddition, the results of this study are in line with the results of research from Trisnaningsih (2007), Rofingatun (2018), Arumsari and Budiartha (2014), Kumiawan et al (2017), Juliningtyas (2012) who found that leadership style had a significant effect on auditor performance

2. Individual capability influences the performance of the auditors of the South Sulawesi provincial inspectorate, indicating that the higher the individual capabilities possessed by an auditor, the higher the auditor's performance. An auditor who has the capability or ability that is good in carrying out his duties will have an impact on increasingly quality performance. The results of this study support the Goal Setting Theory which explains the relationship between goals set with work performance (performance). The results of this study are in line with the research conducted by Supriana (2014), Ongkorohardjo (2008) and Sujana (2012) which concluded that there was a relationship between individual capabilities and auditor performance. This indicates that individual capability is one of the determining factors in improving auditor performance.

3. Motivation affects the performance of the provincial inspector's auditor. Motivation is the driving force for someone to contribute as much as possible for the success of the organization to achieve its goals. The results of this study support the Goal Setting Theory which explains the relationship between goals set with work performance (performance). the basic concept of this theory is that someone who understands the purpose (what is expected by the organization to him) wiU affect his work behavior. Research results from Permana (2016), Marita and Gultom (2018), and Panjaitan and Jatmiko (2014) show that motivation has a significant effect on auditor performance or quality

4. Reward moderates the relationship of leadership style, individual capability, motivation to auditor performance. The results of this study also support the motivational theory of Abraham Maslow formulating that humans in their workplaces are motivated by a desire to satisfy a number of needs that exist within a person. The need for rewards that are positioned as high-level needs is considered to be able to encourage one's performance. The results of this study are in line with the research conducted by the results of this study in line with the research that Zeaud (2012) and Alnsour (2009) showed that rewards have a significant effect on auditor performance. This reaffirms that an agency needs to implement rewards that are liked by its employees, because giving inappropriate rewards will lead to apathetic culture in work so that it will adversely affect the quality of work.

\section{References:-}

1. Akbar, Moch Nizar. 2015. Pengaruh independensi dan profesionalisme terhadap kinerja auditor. Jurnal ekonomi dan bisnis Vol 3 No 2

2. Allen, N. J., dan Meyer, J.P, 2007, The Measurement and Antecedents of Affective, Continuance and Normative Commitment to The Organization. Journal of Occupational Psychology, 63, 1-18.

3. Arens, Alvin A., Elder, dan Beasley. 2008. Auditing dan jasa assurance pendekatan terintegrasijilid 1. Edisi 12. Jakarta : Erlangga

4. Arumsari, Adelia Lukyta, dan Budiartha, I Ketut. 2016. Pengaruh Profesionalisme Auditor, Etika Profesi, Budaya Organisasi, dan Gaya Kepemirnpinan Terhadap Kinerja Auditor Pada Kantor Akuntan Publik Di Bali. E Jurnal Ekonomi dan Bisnis Universitas Udayana Volume 5 Nomor 8, Hal 2297 -2304

5. Alshbeil, Seif Obeid dan Al-Zeaud, Hussein Ali. 2012. Management support and its impact on performance of internal auditors atjordanianpublic industrial shareholding companies. Global journal of international business research vol 5 no 5 .

6. Ayuningtyas, Harvita Yulian, dan Sugeng Pamudji. 2012. Pengaruh pengalaman kerja,Independensi, Obyektifitas, Integritas dan Kompetensi terhadap kualitas hasil audit. Diponegoto Journal Of Accounting. Vol 1 No 2.

7. Azhar, Al. 2013. Pengaruh konflik peran, ketidakjelasan peran, kesan ketidakpastian lingkungan, locus of control dan motivasi kerja terhadap kinerja auditor studi empiris pada kantor akuntan public di pekanbaru, padang dan batam., jumal ekonomi, universitas riau kampus bina widya volume 21, nomor 4

8. Bangun, Wilson. 2012. Manajemen Sumber Daya Manusia. Jakarta. Erlangga

9. Danang, Sunyoto. 2013. Metodologi penelitian akuntansi. Bandung : PT Refika Aditama Anggota Ikapi

10. Dessler, Gary, 2009, Manajemen SOM : Buku 1. Jakarta : Indeks 
11. Djamarah, Syaiful Bahri. 2008. Psikologi Belajar, Jakarta : Rineka Cipta

12. Ganesan, Shankar dan Barton A. Weitz, 1996. The Impact of Staffing Policies on Retail Buyer Job Attitudes and Behavior. Journal of betailing.

13. Ghozali, Imam. 2011. Aplikasi Analisis Multivariate Dengan Program SPSS. Semarang. Badan Penerbit Universitas Diponegoro.

14. Gibson, James, L. 2000. Organization, Behavior, Structure, Process, Edition

15. Hariandja, Marihot. T.E. 2009. Manajemen Sumber Daya Manusia Pengadaan, Pengembangan, Pengkompensasian, clan Peningkatan Produktivitas Pegawai. Jakarta : PT Bumi Aksara.

16. Hasibuan, Malayu S.P. 2016. Manajemen Sumber Daya Manusia. Edisi Revisi. Jakarta : Penerbit PT Bumi Aksara.

17. Julianingtyas, Bunga Nur. 2012. Pengaruh locus of control, gaya kepemimpinan, dan komitmen organisasi terhadap kinerja auditor. Universitas Negeri Semarang. Accounting Analysis Journal 1 Nomor 1, 2012.

18. Kurniawan, Dwi Sumartono Agung, Nadirsyah, dan Syukriy Abdullah. Pengaruh independensi auditor, integritas auditor, profesionalisme auditor, etika profesi, dan gaya kepemimpinan terhadap kinerja auditor di BPK Perwakilan Kota Aceh. Universitas Syiah Kuala. Aceh. Jurnal Magister Akuntansi Volume 6 Nomor 3, hal 49-57.

19. Mangkunegara, Anwar Prabu. 2014. Manajemen Sumber Daya Manusia Perusahaan. Cetakan pertama. Penerbit : Remaja Rosdakarya, Bandung.

20. Marita, dan Gultom, Yossy Purnama Sari. 2018. Pengaruh Profesionalisme, Etika Profesi, Independensi, Motivasi dan Komitmen Organisasi Terhadap Kinerja Auditor Internal (Studi Kasus Pada PT Perkebunan Nusantara IV Medan). Universitas Pembangunan Nasional Veteran Jakarta. Jurnal penelitian ekonomi dan akuntansi, volume III Nomor 1

21. Mayo, Andrew. 2000. The Role of Employee Development in the Growth of Intellectual Capital, Personal Review. Vol. 29 No 4, 2000, pp 521-533.

22. Moeheriono. 2012.Pengukuran kinerja berbasis kompetensi. Jakarta : Raja Grafindo Persada. [36] Moerhad, Griffin. 2013. Perilaku Organisasi : Manajemen Sumber Daya Manusia dan Organisasi. :Edisi 9. Jakarta. Salemba empat

23. Mitchell, Vance F \& Pravin Mondgill. 1967. Organizational Behavior and Measurement of Maslow's Needs Hierarchy.

24. Mulyadi, 2008. Sistem akuntansi, Jakarta : Salemba Empat.

25. Noe, R.A., Hollenbeck, J.R., Gerhart, B. and Wright, P,M. (2008). Human Resource Management : Gaining a Competitive Advantage, New York : Mcgraw Hill.

26. Nurwati. 2012. Pengaruh Kepemimpinan Terhadap Budaya Organisasi, Komitmen Kerja, Perilaku Kerja, dan Kinerja Pegawai (Studi Pada Satuan Kerja Perangkat Daerah Propinsi Sulawesi Tenggara). Jurnal Aplikasi Manajemen, Vol 10 No 1

27. Ongkorohardjo, M.D.P.A, A Susanto dan Rachmawati, 2008. Analisis pengaruh Human Capital Terhadap Kinerja Perusahaan (Studi Empiris pada Kantor Akuntan Publik di Indonesia). Jurnal Akuntansi dan Keuangan, Vol 1. 10, No 1

28. Panjaitan, Anton dan Jatmiko, Bambang. 2014. Pengaruh Motivasi, Stress, dan Rekan Kerja Terhadap Kinerja Auditor (Studi Empiris Pada Kantor Akuntan Publik di DKI Jakarta). Jurnal Bisnis dan Ekonomi, Volume 5 Nomor I

29. Permana, Yockie. 2016. Anal isis pengaruh motivasi, stress, dan rekan kerja terhadap kinerja auditor di kantor badanpengawas keuangan danpembangunan riau dan sumatera utara.

30. Robbins SP, dan Judge. 2008. Perilaku organisasi Buku 2, Jakarta : Salemba Empat. Hal 256. [51] . 2015. Perilaku organisasi Buku 2, Jakarta : Salemba Empat

31. Rofingatun. 2018. Pengaruh independensi dan gaya kepemimpinan terhadap kinerja Auditor (studi pada badan pengawasan keuangan dan pembangunan daerah provinsi papua). Universitas Cendrawasih. Jurnal Akuntansi dan keuangan daerah. Volume 13 Nomor 2.

32. Sawyer, Lawrence B. 2009. Internal Auditing. Buku Satu. Edisi Lima. Jakarta : Salemba Empat Singarimbun, Masri dan Sofyan Efffendy, 1995, Metode Penelitian Survey, Edisi Revisi, PT Pustaka LP3ES, Jakarta

33. Suartana, I Wayan. 2010, "Akuntansi Keperilakuan Teori dan lmplementasi". Yogyakarta : Penerbit Andi.

34. Sudibyo, Yvonne Agustine. 2014. Pengaruh Human Capital Terhadap Kinerja Auditor (Studi Empiris pada Kantor Akuntan Publik di Jakarta. Jurnal Media Riset Akuntansi, Auditing \&lnformasi, Vol 14, No. 2. Agustus. 2014

35. Supriatna, Nono. 2014. Pengaruh Human Capital terhadap Kinerja Auditor pada KAP yang ada di Bandung. Jumal Riset Akuntansi dan Keuangan, Vol. 2, No. 1. 251-260. 
36. Thoha, Miftah. 2010. Kepemimpinan dalam manajemen. Jakarta :Rajawali Pers.

37. Trisnaningsih, Sri. 2007. Independensi Auditor Dan Komitmen Organisasi Sebagai Mediasi Pengaruh Pemahaman Good Governance, Gaya Kepemimpinan Dan Budaya Organisasi Terhadap Kinerja Auditor. Universitas Hasanuddin. Jurnal Penelitian . Volume 10. Hal 1-56.

38. Widhi, Saputra Nugroho dan Setyawati, Erma. 2015. Pengaruh Independensi, Gaya Kepemimpinan, Komitmen Organisasi, dan Pemahaman Good Corporate Governance Terhadap Kinerja Auditor Pemerintah (Studi Empiris Pada BP.KP Perwakilan Jawa Tengah). Universitas Muhammadiyah Surakarta. Jurnal Manajemen dan Bisnis Volume 19, Nomor 1, 2015, Hal 64 - 79

39. Yukl, Gary. 2010. Kepemimpinan dalam organisasi, Edisi Kelima. Jakarta.PT lndeks. 